\title{
Exploring the Impacts of Webquests on Developing Persuasive Writing Skills, Online Social Presence, and Sense of Belonging among ESP Majors
}

* Dr. Ashraf Atta M. S. Salem

\begin{abstract}
The current study explores of the impacts of WebQuests on developing persuasive writing skills. It also aims to assess the actual impacts of the online learning environment on developing online social presence of university students in online learning environments, and sense of belonging among ESP majors. Participants in the study were 72 ESP majors in the College of Management Sciences (CMS), Sadat Academy for Management Sciences (SAMS) in both braches of Alexandria and Tanta; 43 students in the experimental group, and 29 students in the control group. Instruments used in the study include: persuasive writing skills test, Online Social Presence Scale, and Hoffman Sense of Belonging Scale (HSBS). Sequential exploratory mixed research method was used for its appropriacy to the nature of the study. Findings of the study revealed positive impacts on enhancing persuasive writing skills. It is also shown that using this online environment helps learners to improve ESP majors' online social presence. In addition, online social presence and involvement in online learning environment lead to enhancing sense of belonging among ESP majors.

Key Words: WebQuests; Persuasive Writing Skills; Online Social Presence; Sense of Belonging - ESP students.

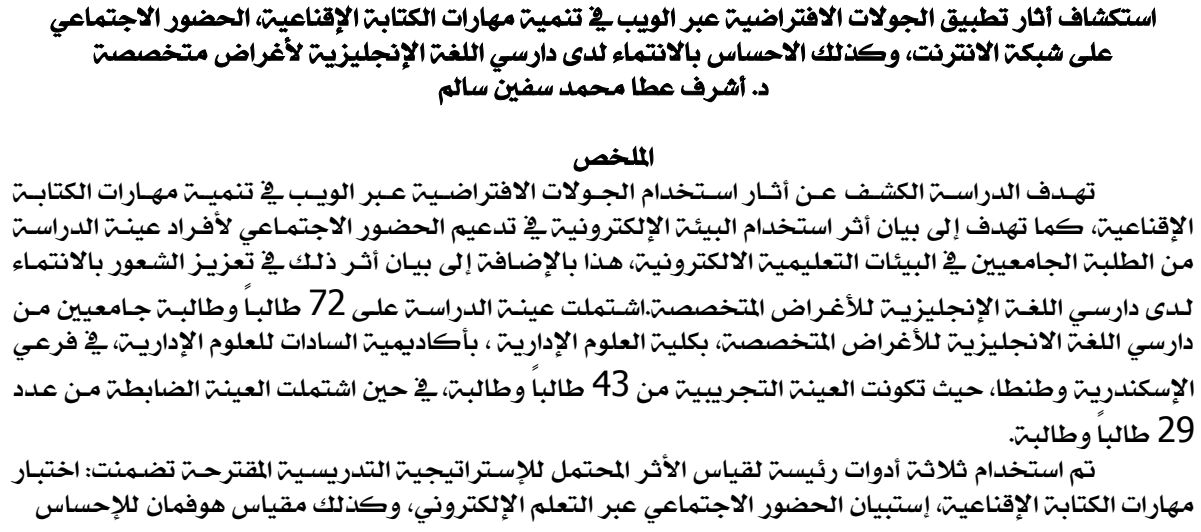

College of Management Sciences, Sadat Academy for Management Sciences, Egypt 


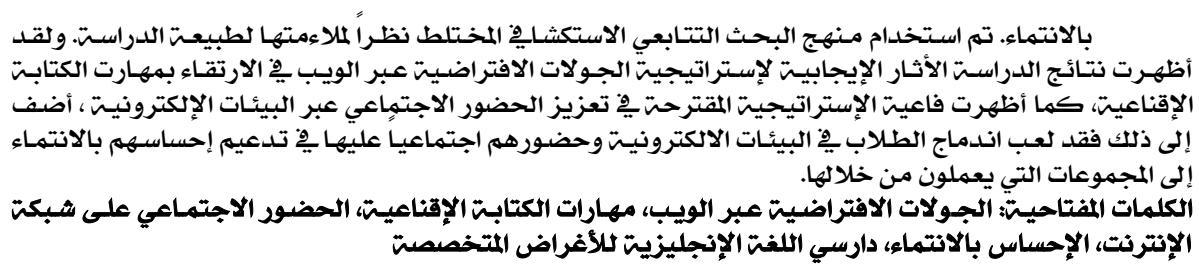

\section{Introduction}

Web 2.0 is a concept which is commonly used to express the second generation web tools that differ from the first generation of web tools in terms of interactivity with the users. The concept of Web 2.0 appeared in a conference session and it was first used by Tim O'Reilly (O'Reilly, 2005). New interactive interfaces have derived as a result of the emergence of the second generation of the Web 2.0. Traditional interface of Web1.0 provides was not rich in term of interactivity between the computer and the users, this results in one-way communication process instead of engaging users in active learning experience in stimuli-rich online environment.

WebQuests is an inquiry-oriented activity that allows students to use the Internet to acquire new knowledge and expand understanding. Webquests refers to virtual journeys and guided online search for information and data, it includes the purposeful search for information necessary to fill certain gaps to consolidate their understanding. Webquest involves the futility of sending students on structured searches for information on the Internet, because there was too much information that was not valid and useful for the students (Dodge, 1995; 1997).

For the learner, a WebQuest represents an inquiry-based activity in which some or all of the information that learners interact with comes from online sources. Throughout the WebQuest, learners follow a specific set of steps towards the completion of a final project on a specific subject or multi-disciplinary subject (Dodge, 1995; 1997; 1998; and 2006). A WebQuest includes an active exploration of the web to get information to do the tasks, it can be viewed as a form of a dialectic constructivism in which both constructivism and instructivism interacts with each other (Segers \& Verhoven, 2009). Constructivism probe for learner's level of 
understanding and the ways in which that understanding can be taken to higher level thinking, it denotes how learners make sense of the material and how they can be taught most effectively (Mvududu, \& Thiel-Burgess, 2012).

Learning is a social activity, it can occur anywhere and anytime, even when and where students are apart from their instructor and peer students. Online learning approaches make this possible, therefore, recent technological developments and distance education encourage more people to become engaged in learning, especially adults. Online learning platforms help adults to continue their learning regardless of the possible barriers such as family or professional responsibility to walk in the traditional classroom (Kim, Kwon \& Cho, 2011).

Online collaboration is an effective tool for improving students' writing skills due to its ability to motivate students to write, enhance their sense of audience, make them aware of the importance of revision, reduce stress in writing, and also cultivate positive attitudes towards writing (Choi, 2008). In addition, education also is social practice (Laffey and Lin, 2006; Shea et al., 2001). Vygotsky's Social Constructivism provided an idea regarding effective and successful learning through facilitating consistent social interaction among students and their instructor. Cognition cannot be promoted in isolation away from emotion; cognitive learning and affects cannot be separated (Delfino \& Manca, 2007).

Social dimension of education provides an impetus for students to form a sound learning community where students develop social bonds which support their academic success. Although social dimension of education entails face-to-face settings with the development of proper instructional design, it just started gaining attention in online learning. There are certain limitations with social dimension with online classrooms as it provide limited visual and communicative signals and cues (Muirhead, 2000; Jolivette, 2006; Kim, Kwon \& Cho, 2011).

Engaging students in online learning experiences needs more efforts from online materials designers to make learners involve in interesting learning practices. Although it lacks stimuli for social interactions, social presence is an indicator of the quality of social interaction in online learning environment including better interpersonal relationships 
between students and their instructors beside effective interpersonal bonds among students.

Online learning materials designers exert much effort to encourage leaners to socially interact with their colleagues through working in virtual pairs and groups. Additionally, in-field instructors should do their best to get students involved in online learning environments to collaborate with each other, which maximizes learners' online social presence. In face-toface learning environments, students in the same group cooperate and collaborate with each other, and they compete with other groups or teams to obtain priority. Collaboration among team members enhances sense of belonging, which leads to better achievement of both hard and soft skills as well as maintaining information learnt. Meanwhile, in online learning environments, students suffer from the dearth of social interactions among learners themselves and between learners and their instructors.

Therefore, the current study tries to investigate the impact of using Webquests on developing both cognitive skills (i.e. persuasive writing skills), and affective constructs (i.e., both online social presence, and sense of belonging) among learners of English to achieve specific purposes in their undergraduate study level. Thus, the following questions should be addressed in the study:

1. Do learners in an online learning environment "WebQuest" achieve higher academic gains in term of their persuasive writing skills compared with their colleagues learning in traditional classrooms?

2. Do learners in an online learning environment "WebQuest" feel high degrees of social presence compared with their colleagues learning in traditional classrooms?

3. Do students learning in an online environments "webquests" feel great sense of belonging compared with students learning in traditional offline environments?

\section{Background}

\section{WebQuests}

Roots of WebQuest can be traced back to the dimensional learning theory of Marzano (1992), it is deeply rooted in the cognitive science 
(Dodge, 1997). Based on dimensional learning theory of Marzano (1992), the learning process involves dynamic interaction between five dimensions of thinking, these dimensions are: (1) development of positive attitudes and perceptions about learning; (2) acquisition and integration of knowledge; (3) extension and refinement of knowledge; (4) meaningful use of knowledge; and (5) development of productive strategies (Segers \& Verhoven, 2009). As a thinking skills based model, Marzano (1992) builds up his assumptions on Bloom's Taxonomy of learning objectives, which described six levels of cognitive processes, commonly perceived as objectives among scholars and practitioners, it includes: knowledge Acquision, comprehension, application, analysis, synthesis, and evaluation. The latter three levels are known as higher-order thinking skills (HOTs), which are assumed to be improved through the WebQuest implementation (Marzano \& Kendall, 2007).

Bernie Dodge and his colleagues in San Diego University, notably David March, designed such a web-based learning model in 1995 as a response to the widespread ICT use in the educational settings. According to Dodge (1997), a typical WebQuest consists of a series of web pages that provide certain structure for the learning process. A WebQuest, whether shortterm or long-term, usually starts with a brief orientation or introduction to a particular shedding the light on background knowledge on the topic and ends in drawing conclusions and evaluation (Dodge, 1997).

The next phase of such guided online quest is to describe the tasks and activities involved. To do the described tasks, learners have to consult certain resources. Thus, in the third phase a list of online resources is provided, which are links to websites related to the topic to help learner to perform the task. The description of processes that learner should follow in their pursuit to perform the prescribed task is provided in the fourth phase of the WebQuest. Processes description is done through several Webpage as it includes explanation of single steps and question guidance to support and even scaffold learners to achieve their goals. The penultimate phase of the WebQuest is the summative evaluation to stand on students' understanding, also to provide feedback when necessary. The WebQuest ends with a conclusion that summarizes the WebQuest educational outcomes as an interesting learning experience. 
Several studies have been conducted to assess the actual gains attained through the use of webquests, almost all of them targeted enhancing the hard skills and thinking skills. None of these skills tried to investigate the effect of using webquests on promoting social presence and sense of belonging, therefore, a research gap has to be filled. Among the studies that have assessed the usefulness of webquests on developing writing skills is the study Hadriana (2017) conducted to investigate the effect of webquests on developing writing skills. It has been revealed that implementing WebQuest helps teachers to creatively bring motivation for the students to learn. ICT integration in English teaching and learning activities facilitate students' learning and increase their interest in the learn process.

Another study, Al-Sayed, et al. (2016) examined the effect of developing the memoir writing skills as a creative non-fiction genre of second year intermediate school high achievers in mainstream language schools using the a WebQuest model. Results showed that the experimental group pupils have developed their skills in memoir writing. It was concluded that WebQuest is effective in fostering the memoir writing skills. It was also recommended that the WebQuest model should be integrated into writing instruction programs.

In another study, Ali (2014) investigated the effect of using WebQuest program on developing some EFL critical reading, process writing skills and decreasing writing apprehension of the first year experimental high school students. Instruments of the study were an EFL critical reading test, writing test and a writing apprehension scale. Results revealed that the experimental group outperformed the control group on post-testing of critical reading skills, their writing skills and further on the postassessment of their writing apprehension levels.

Moreover, the studies which were conducted to stand on the effect of developed academic writing skills and improved thinking skills on reducing writing anxiety of EAP students. In this context, Orozco and Martin (2011) examined the impact of the implementation of WebQuest for learning English in a fifth primary school graders level of communicative competence in English in a public school in Pereira Risaralda. Findings 
revealed that there is a positive impact of the WebQuest strategy on the development of writing and oral skills in English.

In another study, Chu (2004) examined the effect of using WebQuest Writing Instruction on improving students' performance in writing, reducing their writing apprehension. The sample of the study was two second year classes English majors in southern Taiwan. Findings of the study indicated that WebQuest writing instruction improved students' writing performance, reduced their writing apprehension and students had a favorable perception of WebQuest writing instruction.

Although webquests are not activities originally intended for language learning, several researchers have explored their potential for this purpose (Koenraad, 2002; Luzón, 2002; Richards, 2005; Simina \& Hamel, 2005: Al-Khataybeh \& Al-Awasa, 2016; Shafiee, Koosha, \& Afghari, 2013; Fontecha, 2010; Chuo, 2007; Tuan, 2011; MST, 2014; Chen \& Hsiao, 2010; Aqel \& El Alem, 2016), with a due attention directed to the use of webquests for the specific requirements of SLA (Koenraad, 2006, Luzón, 2002). According to Luzón, (2002), webquests help ESP students acquire digital communication skills through providing them with more practice on how to use communication tools effectively. Hence, it helps students to communicate through online communication channels to the degree they form a virtual social community, this increases social presence and online community sense of belonging.

\section{Online Social Presence}

Learning is a social process with discourse playing the key role (Harasim, 2002; Swan \& Shea, 2005; Tu, 2000). Therefore, it is extremely important that we understand how students and teachers socially interact in online learning environments where asynchronous computer mediated communication (CMC) is the major form of discourse (Lowenthal, 2009).

Short, Williams, and Christie (1976) developed the initial theory of social presence to explain the effects a communication medium can have on the way people communicate. In developing such a theory, they depend on the previous research in psychology and communication (i.e., Argyle and Dean's concept of intimacy and Wiener and Mehrabian's concept of immediacy). According to Short et al., social presence is 
viewed as the degree of salience (i.e., quality or state of being there) between two communicators using a communication medium. Social presence is conceptualized as a critical attribute of a communication medium that can determine the way people interact and communicate with each other. Further, it was posited that people perceive some communication mediums as having a higher degree of social presence (e.g., video) than other communication mediums (e.g., audio) (Lowenthal, 2009).

However, in the mid-1990s, researchers who are accustomed with using $\mathrm{CMC}$ for educational purposes began to inquire whether the attributes of a communication medium determined its social presence or the user's personal perceptions of presence. Thus, they argue that CMC can be very social, personal and even hyperpersonal (Garrison, Anderson, \& Archer, 2000; Gunawardena, 1995; Gunawardena \& Zittle, 1997; Swan, 2003b; Walther, 1996).

Researchers discussed social presence in the online learning environment. Three dimensions of social presence-social context, online communication, and interactivity-emerged have been considered as important elements in establishing a sense of community among online learners. The privacy factor was also an important element in the level of comfort for students online. An increase in the level of online interaction occurs with an improved level of social presence. This can be fostered by considering characteristics of the learners, by selecting the appropriate computer-mediated communication medium, and by applying appropriate instructional elements to course design. (Tu \& Marina Mclsaac, 2010).

It is worth noting that, there is not a clear, agreed upon, definition of social presence (Rettie, 2003; Tu, 2002) and researchers continue to redefine it (Picciano, 2002), however, social presence is the concept that is used to examine the quality of social interaction in online learning environment. Social presence was first introduced by Short, Williams, and Christie (1976) to refer to 'the degree of salience of the other person in the interaction and the consequent salience of interpersonal relationships' (p.65). While Gunawardena (1995) regarded social presence as the extent by which others are 'being real' in a mediated environment, 
others defined it as the level of perception or feeling of affective and psychological accessibility (Biocca, Harms, \& Gregg, 2001) or affective connectedness (Tu \& Mclsaac, 2002). Rourke, Anderson, Garrison, and Archer (2001) defined it as 'the ability of learners to project themselves socially and emotionally in a community of inquiry' (p. 53). Meanwhile, Garrison \& Anderson (2003) view that social presence is defined as "the ability of participants in a community of inquiry to project themselves socially and emotionally, as real people through the medium of communication being used"

In Traditional classrooms, students interact with their peers whether in pairs or in groups, also, they interact with instructors. Social interactions occur on a wide range within face-to-face learning environments, meanwhile computer mediated communication (CMC) learning environment lack adequate social presence. According to Rovai (2002), online learning environments, which depend mainly on asynchronous text-based CMC have been criticized for lacking support for social presence, and this lack of support for social presence may keep the sense of belonging and acceptance in a group to minimal.

Social presence has been related with the concepts of intimacy and immediacy (Short et al., 1976; Gunawardena, 1995). Social presence also can be viewed as a quality of the medium itself, i.e., social presence in face to face television differs from that in audio systems in term of four dimensions: unsociable-sociable, insensitive-sensitive, impersonalpersonal, and cold-warm. Since an asynchronous text-based CMC has different attributes from one-way television (Gunawardena,1995), therefore, interactive platforms provided through the Webquests increases the opportunity for students to promote social presence as an attribute of web-based learning.

The role of social presence in online learning can be linked to the larger social context which includes motivation, group unity, verbal and nonverbal communication, and social equality. Almost all these social constructs are very difficult to achieve and maintain in the absence of social presence. It is important to examine social presence in online learning because we need to ensure that despite it being online, it is close 
to a representation of what would be in a face-to-face class (Ngoyi \& Sandy Malapile, 2018).

\section{Sense of Belonging (SOB)}

"People need people - for initial and continued survival, for socialization, for the pursuit of satisfaction. No one not the dying, not the outcast, not the mighty - transcends the need for human contact" (Yalom, 2005, 24). Sense of belonging refers to a feeling of connectedness and belief that one is important and matters to others in an organization, or even the community where he/she lives and works. Based on model developed by Maslow (1954), sense of belonging ranks third on most people's hierarchy of needs, after physiological and safety needs.

One common definition of belonging is "happiness felt in a secure relationship" (Word Net, 2003). Belonging has also been defined as, "the experience of personal involvement in a system or environment so that persons feel themselves to be an integral part of that system or environment" (Hagerty, et.al., 1992, p. 173).

Sense of belonging plays an important role in enhancing students' motivation, concern for others, and positive interpersonal behavior in classroom settings (Edwards \& Mullis, 2001). The importance of belonging was echoed in a statement by Corey (2001), "Only when we have a sense of belonging are we able to act with courage in facing and dealing with our problems" (p. 112). According to Corey, sense of belonging can provide an atmosphere and place for individuals to fulfill their sense of belonging, and allow individuals to recognize that many of their difficulties are interpersonal in nature and that their goals should reflect change in their purposes and interaction within society. Chen, (1999) reported that it represents the power of connectedness and belonging to peoples live, particularly college students.

Walton and Cohen (2007) argued that socially stigmatized groups are less certain about their social bonds and are thus more sensitive to premises that suggest belonging may be difficult in certain environments such as academic settings. Multiple studies have pointed out the negative influence a lack of belonging has with persons who belong to underrepresented groups, particularly in school settings (Jones, 2009). For example, negative impacts include poorer intellectual and academic 
performance (Inzlicht \& Good, 2006; Edwards \& Mullis, 2001; AndersonButcher \& Conroy, 2002; Martin, et.al., 1999), greater risk to physical wellbeing (Gardner et.al, 2005), both positive and negative mental health concepts (Kia-Keating \& Ellis 2007; Menzies \& Davidson, 2002), supports school environments (Edwards \& Mullis, 2001).

Sense of belonging, as a psychological construct, has been studied in relationship to mental health, well-being, and quality of life (e.g., Böhnke, 2005; Choenarom, Williams, \& Hagerty, 2005; Young, Russell, \& Powers, 2004), also, researchers have investigated the mutual relationships between SOB and some key educational outcomes such as academic selfconcept, self-efficacy, intrinsic motivation, academic success, and persistence (e.g., Freeman, Anderson, \& Jensen, 2007; Hausmann, Schofield, \& Woods, 2007; Lovitts, 2001; Ostrove, Stewart, \& Curtin, 2011; Strayhorn, 2012). O'Meara, et al., (2017) reported that sense of belonging has been found to influence college student retention and persistence for undergraduate students (e.g., Freeman et al., 2007; Hausmann et al., 2007; Strayhorn, 2012).

\section{Methods}

The current study used a sequential explanatory mixed-methods approach to collect data. It also did multiple analyses in order to both answer the study questions and to test its hypotheses. Sequential Exploratory Mixed Methods Design (Creswell, Plano Clark, Gutmann, \& Hanson, 2003; Riazi \& Candlin, 2014; Tashakkori \& Teddlie, 2003; Creswell, Plano, \& Clark, 2007; Creswell and Plano Clark, 2011) refers to a research method which explores the previous experiences, and current thoughts and actions of study participants as it includes analyzing both qualitative and quantitative data.

Mixed method research contributes to the development of relevant outcome measures. First, exploratory qualitative components help informing researchers and practitioners about what outcomes are most meaningful and relevant for participants as well as about the most useful format for data collection. In post-hoc evaluations of intervention effects, qualitative examination can identify why differences in intervention outcomes occurred, uncover additional treatment benefits, and explore 
barriers to achieving the best intervention outcomes (Ivankova, Creswell \& Stick, 2006; Kroll \& Morris, 2009).

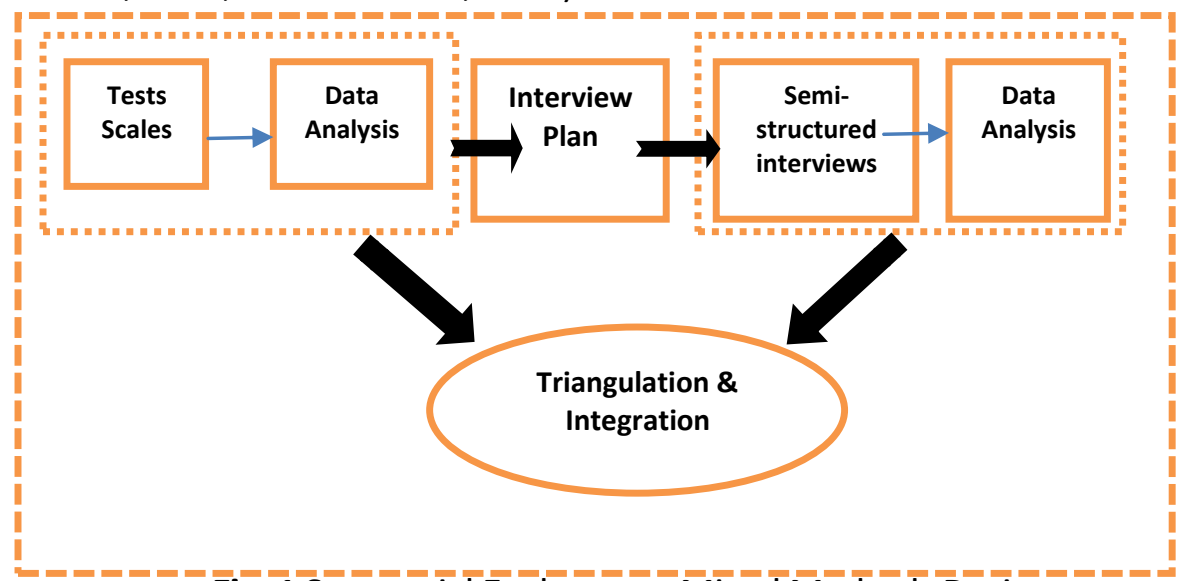

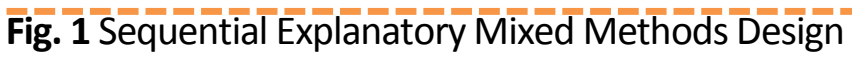

\subsection{Context and participants}

Two intact classes were used in this study; one of these classes was randomly assigned as an experimental group and the other was assigned as a control group. The experimental group, consists of 43 ESP students, and the control group consists of 29, with age range of 19 to 23 studying Business English in the College of Management Sciences (CMS), Alexandria Branch, Sadat Academy for Management Sciences (SAMS), Egypt. The proficiency level of the participants was measured via the Admission test as one of the college entrance requirements and DIALANG, which is an online adaptive diagnostic web-based assessment tool. The results of the DIALANG test, which were reported in levels from $B 1$ to $C 2$, indicated that the participants' writing skills in both groups were at B1 level.

The participants were assured that the results of the study would be used only for the research purpose, and that they would remain strictly confidential. The researcher taught only the experimental group whereas the control group was taught by a well-qualified instructor, who had already taught ESP courses for many years in Tanta branch of CMS. To make sure that results are ascribed only to the effect of the WebQuest the researcher designed prior to the experiment as an online learning strategy adopted in the current study, students in the testing groups 
undertook DIALANG to assess their basic English language proficiency level.

\subsection{Materials and Instruments}

Three main testing instruments were used to assess the actual impacts WebQuests had on the ESP students' persuasive writing skills, online social presence and sense of belonging. Several steps and precautions were taken to ensure no interference of any external uncontrolled factors leading to inaccurate conclusions and implications.

\subsubsection{DIALANG English Proficiency Test}

DIALANG is an online diagnostic system designed to assess non-native speakers of English proficiency in 14 European languages. Competences tested are reading, writing, listening, grammar and vocabulary, while speaking is excluded for technical reasons. DIALANG was designed primarily for European citizens to assess their language abilities in adherence to Europe's Common European Framework of ReferenceCEFR - as a basis for determining language proficiency. The CEFR is a widely recognized framework used to describe and measure the language proficiency level of a learner in a particular language.

DIALANG is neither intended to be used for certification purposes nor to certify language proficiency. The purpose of DIALANG is to offer information regarding a test-taker's strengths and weaknesses in language proficiency. There are no age restrictions for DIALANG testtakers. Yet, it is important to recognize that the tasks written and designed by DIALANG deal with issues that may not be appealing to young learners (Alderson, Huhta, 2005).

\subsubsection{Intervention}

Students in the experimental group, who were introduced to the webquest - an online instructional platform - to enhance persuasive writing skills. Webquests have been used in educational contexts to achieve varied educational goals, such as skills development, evaluation, document assessment, or student projects. There are several websites that can help in producing and designing online webquests, among these websites is the www.zunal.com. Upon signing in the website, teachers can design the parts of the webquest, whether it is a short or a long 
webquest. Teachers can add online materials under the suitable headings and subheadings.

Due attention should be targeted to developing higher-order thinking skills through providing challenging tacks and thinking provoking activities. A list of resources should be carefully chosen to let learners develop selfstudy skills. Zunal.com helps teachers to design webquests with ease of use and simplicity. Practitioners use such a website due to its simplicity of design, use, and implementation. Teachers can register, login and re-login each time easily. Besides, it is easy to create tasks, modify the texts, edit and publish tasks and activity. Zunal.com makes it easy to create attractive, mobile-friendly private pages.

The intervention depends mainly on the process writing approach. Contrasted to the product approach, it focuses mainly on the final product, process approach to writing pays due attention to the successive steps writers go on to reach the final draft. According to Salem (2008, 2013a, 2013b), due to the shortcomings of the product approach, teaching methods have shifted their focus from the written product to the process readers and writers go through to comprehend and be comprehended. The focus is now on the different kinds of strategies and cognitive activities that the writer engages in when writing.

The intervention is based on Mary Ellen Guffey's approach to writing skills development that focuses on process writing. Guffey's scheme (2012) is known as 3-X-3 writing process, it consists of the following:

1. Prewriting: It refers to generating ideas for the writing task, it includes the following: analyze, anticipate, and adapt.

2. Writing: It represents the actual writing, it includes the following steps: research, organize, and compose.

3. Revising: It refers to a polishing and refining process of the finished writing products in the light of the following steps: revise, proofread and evaluate.

Persuasive writing is a form of nonfiction writing that encourages careful word choice, the development of logical arguments, and a cohesive summary. Students can be guided through a series of simple steps in an endeavor to develop their persuasive writing skills. Students learning English for specific purposes, especially those who work in 
finance, economics and marketing need to develop persuasion, it is one of the basic ingredients of their daily job in workplaces.

Effective persuasion depends upon attention to the audience throughout the writing process. To persuade customers to get new products or certain services, customer service personnel or service providers have to use written and spoken persuasive devices to convince listeners or readers. Simply following a traditional formula will not necessarily result in good persuasive writing, hence, students need to investigate the type of audience and specific purpose of the written message affect persuasive writing to arrive at persuasive strategies that work.

Writing an effective persuasive message must not depend on artificial structures that ultimately reduce the act of composition to formulaic practices. Rather, writers have to work effectively from the very beginning to reduce or ultimately get rid of the resistance of the receivers. Persuasion requires a thorough understanding of how to use certain formulas as a guide, it should also be clear that writers have to modify it strategically to fit the needs of the audience and their purposes.

Persuasive writers present ideas to readers, also, they try their best to persuade readers to agree with the writer's point of view. Learning to write persuasively is a crucial 'real life' skill for students. Some examples of persuasive texts include: arguments, expositions, discussions, and letters to the editor, debates, reviews and advertisements.

Persuasive writers need to get their point across effectively are to: 1) be clear about "who", "what" and "why"; 2) target your case on the other person; 3) search for common ground with readers; 4) keep it simple; 5) appeal to "head" and "heart"; 6) be calm and confident; and 7) make it interactive (Tony Manning, 2012).

The ability to persuade can be facilitated via online environments, webquests undoubtedly help writers to use online materials and resources to brainstorm and generate ideas that fit to the topic. Also, online platforms can help writers to organize the ideas students generated. Free online proofreading services are provided to online writers via webquest, writers can use these free online tools to crystalize their written products. Synchronous and asynchronous online 
communication channels support writing quality as it diminishes the effect of time and space boundaries.

Participants in the testing groups were encouraged to write persuasive essays of business nature; 1) CEOs wages are high without reason, 2) You should send past client's thoughtful gifts; 3) You must always know your position in the market; 4) It's smart to create blog posts specific to your business, 5) Word of mouth is still the best way to get you knew clients, 6) Working from home is the best productivity tool, 7) The customer is not always right; and 8) Companies should stop marketing to kids.

\subsubsection{Persuasive writing skills Test}

Participants' persuasive writing skills were assessed twice; before the implementation of the study proposed remedial and instructional online mode for the experimental group and offline modes for the control group, and after the implementation. Participants were studying Mary Ellen Guffey's book "Essentials of business communication" (2016), which focuses on the written as well as the spoken communication skills business English learners need to develop. Persuasive writing skills preposttest depends mainly on Guffey's book, which is business oriented. Participants were asked to write a persuasive essay not less than 5 paragraphs convincing the readers with the issues laying behind the topic.

Students were asked to write the persuasive essay in not more than 30 minutes with 300 word count. The main focus of the raters is placed on three main components: complexity, accuracy, and fluency. Also, a persuasive writing skills rubric has been used to assess the skills developed through the period of implementation side by side with the final product.

The pre-posttests are of the same level of difficulty and deepness; participants are asked to write a persuasive business essay on: "Why cold emailing potential clients actually works". For the purpose of post-testing session, examinees were asked to attempt the following topic: "You should take full advantage of social media for your business".

According to the rubric, scoring the persuasive writing skills followed a scaled score, participants were given a mark from 0 to 30 for the test. Students' scores ranges from 0 representing missing written finished product, 1-16 representing limited writing ability, 17-23 referring to fair 
writing skills, and 24-30 representing good mastery of the target writing skills. To avoid subjectivity in scoring participants' works, two different raters besides the researcher scored the participants' writings, the total marks given by the 3 raters were divided by 3 to get the average argumentative writing scores.

\subsubsection{Social Presence Scale}

The SPQ (Lin, 2004) consists of 12 items distributed among three subscales assessing aspects of student social presence in online learning environment in a college setting. The factor analysis resulted in three factors which explained $73.889 \%$ of total variance were named as "perception of the assistance of group activity to learning", "social comfort of expressing and sensing affect", and "social navigation". Cronbach's coefficient alpha was computed for the 12 item social presence questionnaire as a test of internal consistency. Cronbach's coefficient alpha values for three factors were $0.86,0.89$, and 0.76 respectively. Alpha of the entire questionnaire of 12 items was 0.84 . The scale's reliability met acceptable standards of 0.73 and above and can be interpreted as internally consistent or as measuring the same phenomenon (Bowers \& Courtright, 1984).

\subsubsection{Sense of Belonging Scales.}

The SOBS (Hoffman et al., 2002-2003) consists of 26 items distributed among five subscales assessing aspects of student belongingness in a college setting. These items encompass peer-to-peer relationships, student to faculty relationships, and classroom-specific interactions.

The scales are perceived peer support ( 8 items; $a=.84$ ), perceived faculty support/comfort ( 6 items; $a=.84$ ), perceived classroom comfort (4 items; $a=.87$ ), perceived isolation ( 4 items; $a=.82$ ), and empathetic faculty understanding ( 4 items; $a=.84)$. Items are measured using a Likert-type scale anchored by 1 (completely true) to 5 (completely untrue). Lower scores on the SOBS are indicative of a higher sense of belonging (SB). A sample item for the perceived classroom comfort scale is "It is difficult to meet other students in class." 


\section{Results}

\subsection{The quantitative analysis}

Participants were both pre-tested and post-tested using the three testing tools; Persuasive writing skills, online social presence questionnaire, and Hoffman Sense of Belonging Scale (SOB). The statistical differences between the mean scores of the pretest and posttest in the two groups have been investigated through the use of tTest for inferential statistic. T-test was calculated upon the participants' scores of the pre-testing and post-testing.

The primary research question of this study is whether the use of online learning platforms, i.e., webquests, help developing business majors' persuasive writing skills. The essence of the question is to investigate the effectiveness of using online versus offline learning on enhancing ESP students' persuasive writing skills. The researcher designed the webquest including vivid activities and tasks to help learners develop their persuasive writing skills. It should be noted that no experimental treatment were offered to learners in the control group except the traditional teaching practices.

Table 1 presents the descriptive statistics for the scores obtained under the two treatment conditions (Webquests and traditional classroom) on the business majors' persuasive writing skills.

\begin{tabular}{|c|l|l|c|c|}
\hline Group & $\begin{array}{c}\text { Pretest } \\
\text { scores }\end{array}$ & $\begin{array}{c}\text { Posttest } \\
\text { scores }\end{array}$ & $\begin{array}{c}\text { Posttest } \\
\text { Observed } \boldsymbol{t} \text {-value }\end{array}$ & $\begin{array}{c}\text { Cohen's } \\
\text { effect size } \boldsymbol{d}\end{array}$ \\
\hline Control & $10.75(1.64)$ & $11.04(1.36)$ & & \\
\hline Experimental & $10.66(1.83)$ & $22.66(2.53)$ & $46.99^{*}$ & 5.43 \\
\hline
\end{tabular}

$* \mathrm{P} \leq .001$

It is clear from the data presented in table 1 that there are statistically significant differences between mean scores of the experimental and control groups in the posttest of the persuasive writing skills. It is revealed that the experimental group, who were taught through webquests, surpassed their colleagues in the control group, who received traditional teaching practices.

The second research question addressed in the study is whether the use of webquests, as an online learning environment, helps ESP students to promote online social presence. It is really a challenging issue to ensure 
high levels of social presence through online interactions, it is a logic faceto-face learning environments include high levels of social presence. On the contrary, learners interact through online learning environments suffer from the deficiency of face-to-face interactions, and the social relationships. Therefore, the main focus here is to make sure that students are able to interact with each other and build social bonds leading to high levels of social presence.

Table 2 presents the descriptive statistics for the scores obtained under the two treatment conditions (webquests and traditional teaching classroom) on the business majors' social presence.

\begin{tabular}{|c|c|c|c|c|c|}
\hline Dimension & Groups & Pre-testing & Posttesting & $\begin{array}{c}\text { Posttest } \\
\text { Observed } \\
t \text {-value }\end{array}$ & $\begin{array}{c}\text { Cohen's } \\
\text { effect } \\
\text { size } d\end{array}$ \\
\hline \multirow{2}{*}{$\begin{array}{c}\text { Perception of } \\
\text { the assistance of } \\
\text { group activity to } \\
\text { learning }\end{array}$} & Control & $10.20(1.73)$ & $10.48(1.61)$ & \multirow[b]{2}{*}{26.316} & \multirow[b]{2}{*}{6.41} \\
\hline & Experimental & $10.83(1.46)$ & $20.25(1.43)$ & & \\
\hline \multirow{2}{*}{$\begin{array}{c}\text { Social comfort } \\
\text { of expressing } \\
\text { and sensing } \\
\text { affect }\end{array}$} & Control & $8.00(1.53)$ & $8.48(1.61)$ & \multirow[t]{2}{*}{21.360} & \multirow[t]{2}{*}{5.25} \\
\hline & Experimental & $8.62(1.19)$ & $16.13(1.28)$ & & \\
\hline \multirow{2}{*}{$\begin{array}{c}\text { Social } \\
\text { navigation }\end{array}$} & Control & $6.10(1.23)$ & $6.31(1.16)$ & \multirow[t]{2}{*}{20.605} & \multirow[t]{2}{*}{4.74} \\
\hline & Experimental & $6.34(1.02)$ & 12.11(1.17) & & \\
\hline \multirow[t]{2}{*}{ Total } & Control & 24.31(3.72) & $25.27(3.20)$ & \multirow[t]{2}{*}{31.626} & \multirow[t]{2}{*}{7.70} \\
\hline & Experimental & $25.81(2.47)$ & $48.51(2.82)$ & & \\
\hline
\end{tabular}

\section{$* \mathrm{P} \leq .001$}

The secondary research question that need to be addressed is whether participation in online activities and tasks provided in an online learning platform, webquests, help learners to get involved in online pair and group work, which enhance their social presence in online learning environments. As such, it is essential to stand on the students' actual behaviors in online learning platforms, the opportunities to work as a group in which every member has the opportunity to participate in activities, to cooperate with other members, and to collaborate actively with them. The main concern here is to assure full indulgence in virtual communities the same way they are involved in the offline learning communities. There is no logic to aspire complete social presence in the online learning environments the same way that to witness complete 
social absence in face-to-face learning environments. Therefore, it is satisfactory to achieve high levels of social presence, our concern is the

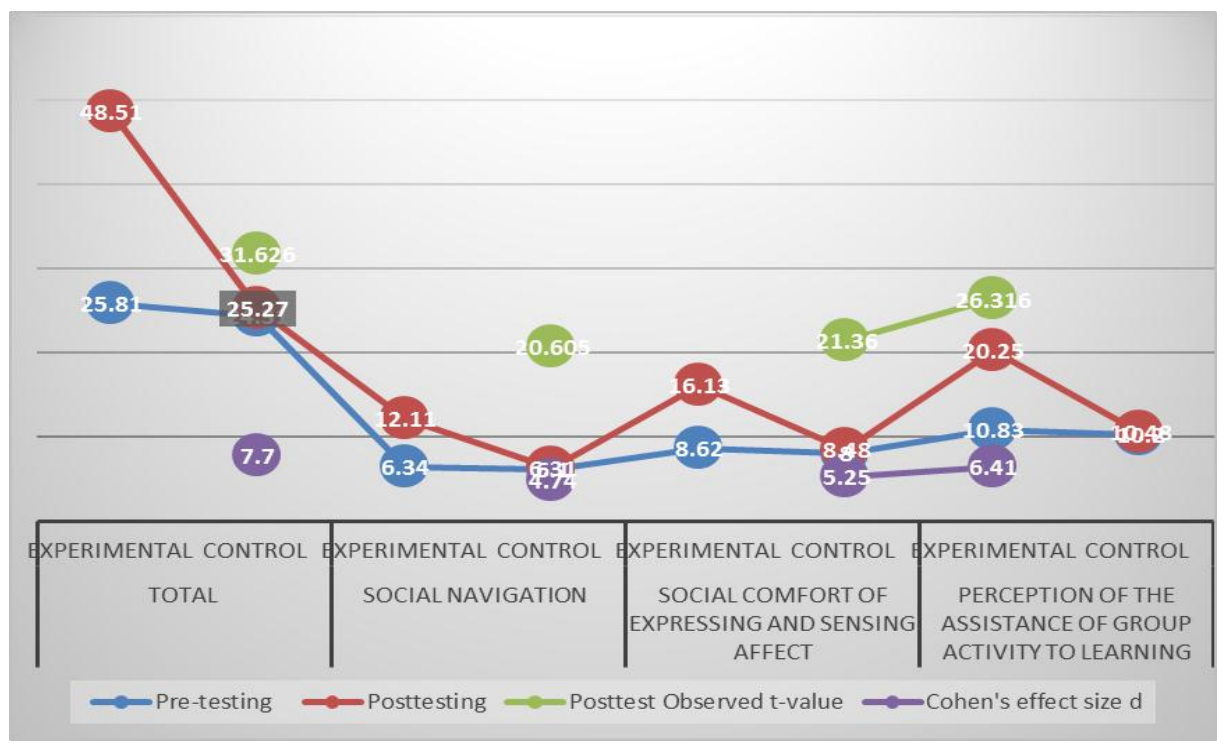

degree of social participation.

Fig. 2 Descriptive statistics for the scores obtained under the two treatment conditions on the business majors' social presence.

Establishing one's social presence in online learning environments can be difficult due to limited communication channels and transactional distance (Moore, 2007). Thus, webquests provide learners with various channels of communication to help learners to cooperate and collaborate with each other to increase the social presence. According to Christopherson, (2007), learners in online learning environments have varying degrees of social presence, based largely on the type and degree of contribution in the class; whether they are socially anonymous depends not on their volume of contributions but rather the degree to which they share identity cues within their course communications.

The third research question addressed in the current study is whether participation in online activities and tasks provided in an online learning platform, webquests, which enhanced students' social presence leads to higher sense of belonging. Taking parts in online group discussion, cooperating with other colleagues and working collaboratively in a team 
promotes the students' sense of belonging to the group they are working with. Sense of belonging to the group is an initial step to enhance the same sense towards larger groups till it reaches the home or the society.

Table 3 presents the descriptive statistics for the scores obtained under the two treatment conditions (Webquests and traditional teaching classroom) on the business majors' sense of belonging.

\begin{tabular}{|c|c|c|c|c|c|}
\hline Dimensions & Group & $\begin{array}{l}\text { Pretest } \\
\text { scores }\end{array}$ & $\begin{array}{l}\text { Posttest } \\
\text { scores }\end{array}$ & $\begin{array}{c}\text { Posttest } \\
\text { Observed t- } \\
\text { value }\end{array}$ & $\begin{array}{c}\text { Cohen's } \\
\text { effect } \\
\text { size d }\end{array}$ \\
\hline \multirow{2}{*}{$\begin{array}{c}\text { Perceived } \\
\text { Peer Support }\end{array}$} & Control & $16.00(2.37)$ & $16.72(2.50)$ & \multirow[b]{2}{*}{28.356} & \multirow[b]{2}{*}{6.91} \\
\hline & Experimental & $16.97(2.13)$ & $33.00(2.20)$ & & \\
\hline \multirow{2}{*}{$\begin{array}{c}\text { Perceived } \\
\text { Classroom } \\
\text { Comfort }\end{array}$} & Control & $8.17(1.46)$ & $8.55(1.21)$ & \multirow[t]{2}{*}{27.151} & \multirow[t]{2}{*}{6.52} \\
\hline & Experimental & $8.41(1.43)$ & $16.48(1.22)$ & & \\
\hline \multirow{2}{*}{$\begin{array}{l}\text { Perceived } \\
\text { Isolation }\end{array}$} & Control & $8.13(1.76)$ & $8.58(1.54)$ & \multirow[t]{2}{*}{21.933} & \multirow[t]{2}{*}{5.31} \\
\hline & Experimental & $8.25(1.48)$ & $16.60(1.48)$ & & \\
\hline \multirow{2}{*}{$\begin{array}{l}\text { Perceived } \\
\text { Faculty } \\
\text { Support } \\
\end{array}$} & Control & $20.65(3.11)$ & $21.72(2.20)$ & \multirow[t]{2}{*}{36.579} & \multirow[t]{2}{*}{8.75} \\
\hline & Experimental & $21 / 13(2.94)$ & $41.39(2.29)$ & & \\
\hline \multirow[t]{2}{*}{ Total } & Control & $52.96(4.94)$ & $55.58(5.94)$ & \multirow[t]{2}{*}{37.780} & \multirow[t]{2}{*}{9.17} \\
\hline & Experimental & $54.79(5.59)$ & $107.49(5.36)$ & & \\
\hline
\end{tabular}

It is evident that online learning environments, webquests, help increasing the students' sense of belonging to certain circles of environments; the virtual group/team, the educational institution and then the whole society. Using webquests undoubtedly help learners to get involved in the groups, which turned to be similar to social bonds, involving in online activities represent interesting learning experiences, it is an effective tool then to help learners to increase their sense of belonging. 
Descriptive statistics for the scores obtained on the business majors' sense of belonging

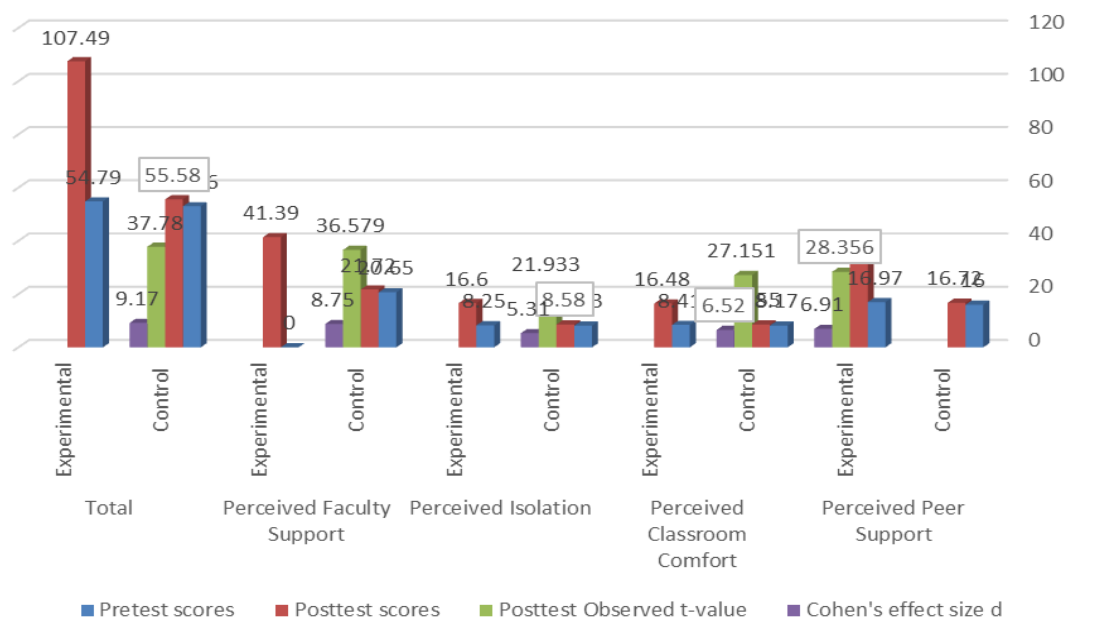

Fig. 3 Descriptive statistics for the scores obtained under the two treatment conditions on the business majors' sense of belonging.

\section{b) The qualitative analysis}

Having analyzed the transcribed semi-structured interviews through thematic analysis some themes emerged, the results of which are presented in Table 5.

Table 4. Themes of the EAP learners' attitudes and perceptions towards the impact of WebQuest on persuasive writing skills, online social presence, and sense of belonging

\begin{tabular}{|c|c|c|c|}
\hline No. & Themes & Explanation & Example \\
\hline 1 & $\begin{array}{l}\text { Interest \& } \\
\text { Motivation }\end{array}$ & $\begin{array}{l}\text { Learning through webquests - as } \\
\text { one of the online learning platforms } \\
\text { - provides learners with interesting } \\
\text { experiences. Students expressed } \\
\text { their interests to learn in such } \\
\text { motivating environment. Unlike } \\
\text { traditional offline teaching contexts, } \\
\text { students are highly motivated to } \\
\text { learn in a meaningful context. }\end{array}$ & $\begin{array}{l}\text { S1: I have been } \\
\text { learning English for } \\
\text { more than } 13 \text { years in } \\
\text { traditional } \\
\text { classrooms, in which } \\
\text { both teachers and } \\
\text { students lack of } \\
\text { interest. Therefore, } \\
\text { webquests represents } \\
\text { a wonderful learning } \\
\text { experience. }\end{array}$ \\
\hline
\end{tabular}




\begin{tabular}{|c|c|c|c|}
\hline 2 & $\begin{array}{c}\text { Change of focus } \\
\text { (Teachers'/learners } \\
\text { Role) }\end{array}$ & $\begin{array}{l}\text { Web-based learning approaches } \\
\text { include a change in teachers' and } \\
\text { learners' roles; teachers are no } \\
\text { longer the dominant in the whole } \\
\text { process, learners play vital roles to } \\
\text { learn rather than are passive } \\
\text { listeners. Unlike traditional } \\
\text { instruction mode; the dominating } \\
\text { role of teachers changed to be a } \\
\text { consultant, advisor, and a success } \\
\text { partner. }\end{array}$ & $\begin{array}{l}\text { S2: I feel that I am } \\
\text { myself in this } \\
\text { experiment, I am no } \\
\text { longer passive } \\
\text { listener or free rider } \\
\text { (as Dr. Ashraf said) in } \\
\text { the learning } \\
\text { experience. }\end{array}$ \\
\hline 3 & $\begin{array}{c}\text { Interactions \& } \\
\text { effective } \\
\text { communications. }\end{array}$ & $\begin{array}{l}\text { Interactions between learners and } \\
\text { their teacher from the one hand } \\
\text { and among learners is of important } \\
\text { features of online learning } \\
\text { environments. }\end{array}$ & $\begin{array}{l}\text { S3: I have enough } \\
\text { time to communicate } \\
\text { with my colleagues } \\
\text { whether inside or } \\
\text { outside the } \\
\text { classroom, there are } \\
\text { several } \\
\text { communication } \\
\text { channels. }\end{array}$ \\
\hline 4 & $\begin{array}{l}\text { Digital literacy } \\
\text { skills }\end{array}$ & $\begin{array}{l}\text { Besides developing hard and soft } \\
\text { skills, online learning environments } \\
\text { provide learners with opportunities } \\
\text { to be exposed to online platforms } \\
\text { to help them develop their digital } \\
\text { literacy skills. }\end{array}$ & $\begin{array}{l}\text { S4: I am going to join } \\
\text { IT section in the } 3^{\text {rd }} \\
\text { year of my university } \\
\text { study, therefore, I am } \\
\text { grateful to Dr. Ashraf } \\
\text { for giving me such } \\
\text { opportunity to } \\
\text { enhance my digital } \\
\text { literacy and } \\
\text { information } \\
\text { technology } \\
\text { awareness. }\end{array}$ \\
\hline 5 & Active learning & $\begin{array}{l}\text { In the webquest, students } \\
\text { participate actively in preparing } \\
\text { materials, judging the quality of the } \\
\text { resources, and learn on their own } \\
\text { pace. Students are therefore active } \\
\text { learners while teachers scaffold } \\
\text { their learning. }\end{array}$ & $\begin{array}{l}\text { S5: I did not feel shy } \\
\text { to take part in the } \\
\text { diverse activities in } \\
\text { this course because I } \\
\text { can work and learn } \\
\text { on my own speed. }\end{array}$ \\
\hline
\end{tabular}


Findings generally indicated positive perceptions and attitudes business majors towards the impact of webquests on developing hard cognitive and psychological skills; persuasive writing skills, online social presence, and sense of belonging which further coupled with the quantitative findings. Therefore, mixed method analysis of both quantitative and qualitative data obtained from the statistical treatment of testing processes and the semi-structured interviews with participants after the experimentation.

Students' casual responses reflected positive attitudes towards implementing webquests as an online learning platform in order to develop multitude of skills. Also, involving in online learning activities provide learners with interesting experiences, it instill the spirit of cooperation which leads to belonging to certain groups. Students who were reluctant to participate in the study experiment pushed to involve as soon as they are exposed to the activities offered in the webquests, they expressed their joy and entertainment.

\section{Discussion}

Web-based learning is designed mainly to help learners make effective use of time, support their thinking skills and actively involve at the levels of analysis, synthesis, transformation of information, decision making, and evaluation (Ikpeze and Boyd, 2007; Ridgeway, Peters \& Tracy, 2002). Webquest proves to be effective on scaffolding higher-thinking skills and accelerate the process of self-learning. It also develops knowledge acquisition (Spiro, Coulson, Feltovich, \& Anderson, 1994).

The findings are in line with those of Ebadi and Rahimi (2018) who found significant and positive impact WebQuest-based classroom on EFL learners' critical thinking and academic writing skills, and those of Ebadi, Rahimi, \& Harati (2017) who found positive impacts of WebQuest-based flipped classroom on EFL learners' critical thinking and academic writing skills. The findings in this regard could be due to the structural differences of webquests in the one hand and traditional learning on the other.

Webquest depends mainly on scaffolding techniques which are designed to promote a deeper level of learning. It supports teachers during the learning process and tailors their teaching practices to the students' needs with the intention of helping students achieve their 
learning goals. Instructional scaffolding is given according to the students' needs; not all learners need support, and not all of them need support to the same degree or forever.

Unlike traditional teaching methods, online learning environments increase learners' motivation to learn. Also, it pays due attention to individual differences among learners when designing teaching activities and learning materials. WebQuests model depends on student-centered approach, it includes learners participate actively in the process of preparing the course material by providing the learners with various webbased resources to work independently.

However, the positive impact of webquest should not be overemphasized, there are certain drawbacks that appear through actual implementation of webquests in the formal schooling contexts. Alshammari (2015) concurs that one of the prominent drawbacks of using webquests include the navigational confusion that arises due to the acquisition of too much information in a webquest. According to Kurt (2012), too much information in a webquest might overwhelm learners and consequently cause them to lose track of the subject they are studying. Therefore, scaffolding the online environment is necessary to help and guide learners during the learning process.

The findings of the study in regards to the social presence enhancement revealed the value of webquest model, as it is based on constructivism, self-directed learning, collaborative learning, situated learning and scaffolded learning (Chen \& Hsiao, 2010). In addition, technology-integrated language learning yields positive learning outcomes (Ottenbreit-Leftwich et al., 2010; Shieh, 2012), these online learning environments also include openness, personalization, social presence and collective wisdom for both learners and instructors (O'Reilly, 2005; Dabbagh \& Reo, 2011). Moreover, online learning environment plays a great role in shaping collaboration among learners (Stahl et al., 2013).

Among other priorities of the online environments like webquest is the qualified teachers who are able to promote thinking skills, especially higher-order thinking skills. As Chuang (2016) states, teacher training is crucial to cope with new technologies involved in the online 
environments, cloud computing and social networking are among these trends. Therefore, webquests provide learners with unparalleled opportunities to focus on the use and finding quality information on the internet, it also helps students develop autonomy to do their work, share opinions, discuss and solve problems (Barros \& Carvalho, 2007; Oliver, 2010; Puthikanon, 2009).

In line with the present study, Awada \& Ghaith (2014) claim that the learners' satisfaction and positive attitudes have led to minimized writing task apprehension due to the student-centered feature of the sheltered online instruction environments. The reason behind such findings could be due to some characteristics of the webquests which include collaborative work, scaffolding practices, active learning and inquirybased activities. Learners enjoy using the webquest, which they believe to help them feel ownership of their learning, also the use of authentic materials, activities and tasks is a great merit.

\section{Conclusion}

EFL scholars and practitioners are encouraged to use webquests to design interactive online learning environments to provide learners the authentic instructional materials side by side with formative online assessment. It also makes learners to feel ownership of their learning, they can participate actively in designing online materials and other learning activities. Webquests lays the foundations of constructivist learning that is revealed to be effective on developing academic skills besides its promising impacts on improving soft skills that are crucial for study and career opportunities.

Implementing webquest as an online learning platform as well as learning strategy supports learning through saving time for more interactions, which helps in developing hard skills that cannot be easily developed through traditional instructional practices. Technologyintegrated sheltered instruction approaches provide learners with online resources carefully selected so as to guide learners to find the necessary information. It helps learners to develop higher thinking skills, solve problems, and construct knowledge that is most meaningful to them.

EFL teachers are further recommended to sufficiently activate scaffolding, active learning, deep learning, collaborative peer work, and to 
encourage learners to be responsible of their own learning. Due to the merits of using webquests, teachers are recommended to implement it in language learning sessions. It is also recommended to use such model on improving thinking skills, especially higher-order thinking skills, it also helps on creating positive attitudes towards language skills especially with non-native speakers of English. 


\section{References}

1. Alderson, J. Ch., Huhta, A. (2005). The development of a suite of computer-based diagnosis tests based on the Common European Framework. Language Testing, 22 (3), 301.

2. Ali, M. A. E. (2014). The Effect of Using a Web Quest Program on Developing Some EFL Critical Reading Process Writing Skills and Decreasing Writing Apprehension of the First Year Experimental Secondary School Students. AWEJ, 5 (1), 197-210.

3. Al-Khataybeh, M. M. \& Al-Awasa, A. S. (2016). The effect of WebQuests on improving seventh grade female students' writing skills in Southern Al-Mazar Directorate of education. Journal of Education \& Social Policy, 3(1): 112-127.

4. Al-Sayed, R. K. M.; Abdel-Haq, E. M.; El-Deeb, M. A. and Abdel-Sadeq M. (2016). Fostering the Memoir Writing Skills as a Creative NonFiction Genre Using a WebQuest Model. Benha Faculty of Education Journal, March (2016).

5. Alshammari, A. (2015). Effectiveness of using WebQuest to teach computer science to middle school students in Saudi Arabia. Master's Thesis/Project Capstone, State University of New York at Fredonia Fredonia, New York.

6. Anderson-Butcher, D. \& Conroy, D.E. (2002). Factorial and Criterion Validity of Scores of a Measure of Belonging in Youth Development Programs. Educational and Psychological Measurement. 62(5).

7. Aqel, M. S. \& El Alem, T. (2016). The impact of using WebQuest on developing websites design skills among faculty of education students. IOSR Journal of Research \& Method in Education (IOSRJRME), 6(6): 30-37. DOI:10.9790/7388-0606063037.

8. Awada, Gh., and Ghaith, Gh., (2014). Impact of Using the WebQuest Technological Model on English as a Foreign Language (EFL) Writing Achievement and Apprehension. AWEJ Special Issue on CALL, 81 -93.

9. Barros, A. \& Carvalho, A. (2007). From a WebQuest to a ReadingQuest: learners' reactions in an EFL extensive reading class. Interactive Educational Multimedia,15, 37-51. 
10. Biocca, F., Harms, C., \& Gregg, J. (2001). The networked minds measure of social presence: pilot test of the factor structure and concurrent validity. Proceedings of the 4th annual international workshop on presence. Philadelphia.

11. Böhnke, P. (2005). First European quality of life survey: Life satisfaction, happiness and sense of belonging. Luxembourg City, Luxembourg: Office for Official Publications in the European Communities.

12. Chen, F. S. \& Hsiao, Y. W. (2010). Using WebQuest as a creative teaching tool at a science and technology university in Taiwan. World Transactions on Engineering and Technology Education, 8(2): 203206.

13. Choenarom, C., Williams, R. A., \& Hagerty, B. M. (2005). The role of sense of belonging and social support on stress and depression in individuals with depression. Archives of Psychiatric Nursing, 19(1), 18-29. https://doi.org/10.1016/j.apnu.2004.11.003

14. Choi, J. W. (2008). The Role of Online Collaboration in Promoting ESL Writing. English Language Teaching, 1(1), 34-49.

15. Christopherson, K. M. (2007). The positive and negative implications of anonymity in internet social interactions: On the internet, nobody knows you're a dog. Computers in Human Behavior, 23, 3038-3056. doi:10.1016/j.chb.2006.09.001

16. Chu, T. I. (2004). The effect of the WebQuest writing instruction on EFL learners' writing performance, writing apprehension, A Dissertation of PhD Thesis, La Sierra University.

17. Chuang, H. (2016). Leveraging CRT awareness in creating web-based projects through use of online collaborative learning for pre-service teachers. Educational Technology Research and Development, 64(4):857-876.

18. Chuo, T. I. (2007). The effect of the WebQuest writing instruction program on EFL learners' writing performance, writing apprehension, and perception. TESL-EJ, 11(3), 1-27.

19. Corey, G. (2001). Theory and Practice of Counseling and Psychotherapy 6th edition. Belmont, CA: Wadsworth/Thomson Learning. 
20. Creswell, J. W., \& Plano Clark, V. L. (2007). Designing and conducting mixed methods research. Thousand Oaks, CA: Sage.

21. Creswell, J. W., Plano Clark, V. L., Gutmann, M., \& Hanson, W. (2003). Advanced mixed methods research designs. In A. Tashakkori \& C. Teddlie (Eds.), Handbook on mixed methods in the behavioral and social sciences (pp. 209-240). Thousand Oaks, CA: Sage Publications.

22. Dabbagh, N., \& Reo, R. (2011). Impact of Web 2.0 on higher education. In D. W. Surry, T. Stefurak, \& R. Gray (Eds.), Technology integration in higher education: Social and organizational aspects (pp. 174-187). Hershey, PA: IGI Global.

23. Dodge, B. (1995). WebQuests: A technique for Internet-based learning. Distance Educator, 1(2), 10-13.

24. Dodge, B. (1997). Some Thoughts about WebQuests. San Diego State University. Retrieved April 2, 2010, from http://webquest.sdsu.edu/about webquests.html.

25. Dodge, B. (1998). WebQuests: A strategy for scaffolding higher level learning. Retrieved March7, 2014 from http://webquest.sdsu.edu/necc98.htm

26. Dodge, B. (2006). WebQuests: Past, Present and Future. San Diego State University.

27. Ebadi, S. \& Rahimi, M. (2018). An exploration into the impact of WebQuest-based classroom on EFL learners' critical thinking and academic writing skills: a mixed-methods study. Computer Assisted Language Learning, 31, 1-35. Doi:10.1080/09588221.2018.1449757.

28. Ebadi, S.; Rahimi, M. \& Harati, H. (2017). Exploring the impact of WebQuest-based flipped classroom on EFL learners' critical thinking and academic writing skills. A paper presented in CALL Conference in 2017, At Berkeley, University of California.

29. Edwards, D. \& Mullis, F. (2001). Education: Teaching the IdeasCreating a Sense of Belonging to Build Safe Schools. The Journal of Individual Psychology. 57(2).

30. Fontecha, A. F. (2010). The CLILQuest: A type of language WebQuest for content and language integrated learning (CLIL). CORELL: Computer Resources for Language Learning, 3, 45-64. 
31. Freeman, T. M., Anderson, L. H., \& Jensen, J. M. (2007). Sense of belonging in college freshmen at the class-room and campus levels. The Journal of Experimental Education, 75, 203-220. https://doi.org/10.3200/JEXE.75.3.203-220

32. Gardner, W.L., Pickett, C.L., Jefferis, V., \& Knowles, M. (2005). On the Outside Looking In: Loneliness and Social Monitoring. Personality and Social Psychology Bulletin. 31(11), 1549-1560.

33. Garrison, D. R., Anderson, T., \& Archer, W. (2000). Critical inquiry in a text-based environment: Computer conferencing in higher education. The Internet and Higher Education, 2(2-3), 87-105.

34. Garrison, D. R., Cleveland-Innes M., \& Fung, T.S. (2004). Student role adjustment in online communities of inquiry: model and instrument validation. Journal of Asynchronous Learning Networks, 8(2): 61-74.

35. Gunawardena, C. N. (1995). Social presence theory and implications for interaction and collaborative learning in computer conferences. International Journal of Educational Telecommunications, 1(2/3):147-166.

36. Gunawardena, C. N., \& Zittle, F. J. (1997). Social presence as a predictor of satisfaction within a computer-mediated conferencing environment. The American Journal of Distance Education, 11(3), 826.

37. Hadriana, A. (2017). WebQuest application to improve English writing skill. International Journal of Software Engineering and Its Applications, 11(4), 61-68, http://dx.doi.org/10.14257/ijseia.2017.11.4.05.

38. Hagerty, B.M.K., Lynch-Sauer, J., Patusky, K., Bouwseman, M., \& Collier, P. (1992). Sense of belonging: a vital mental health concept. Archives of Psychiatric Nursing. 6,172-177.

39. Harasim, L. (2002). What makes online learning communities successful? The role of collaborative learning in social and intellectual development. In C. Vrasidas \& G. V. Glass (Eds.), Distance education and distributed learning (pp. 181-200). Greenwich, CT: Information Age Publishing. 
40. Hausmann, L., Schofield, J., \& Woods, R. (2007). Sense of belonging as a predictor of intentions to persist among African American and white first-year college students. Research in Higher Education, 48(7), 803-839. https://doi.org/10.1007/s11162-007-9052-9

41. Hoffman, M., Richmond, J., Morrow, J., \& Salomone, K. (2002). Investigating "sense of belonging" in first-year college students. Journal of College Student Retention: Research, Theory \& Practice, 4(3), 227-256. https://doi.org/10.2190/DRYC-CXQ9-JQ8V-HT4V

42. Ikpeze, C.H., and B.F. Boyd. (2007). Web-based inquiry learning: facilitating thoughtful literacy with WebQuests. The Reading Teacher 60 (7): 644-654.

43. Inzlicht, M. \& Good, C., (2006). How environments can threaten academic performance, self-knowledge, and sense of belonging. In Levin, S., \& Van Laar, C. (Eds.), Stigma and Group Inequality: Social Psychological Perspectives. Mahwah, NJ: Lawrence Erlbaum Associates.

44. Ivankova, N. V., Creswell, J. W., \& Stick, S. L. (2006). Using mixedmethods sequential explanatory design: From theory to practice. Field Methods, 18(1), 320.Doi:http://dx.doi.org/10.1177/1525822X05282260

45. Johnson, D. R., Soldner, M., Brown Leonard, J., Alvarez, P., Inkelas, K. K., Rowan-Kenyon, H., \& Longerbeam, S. (2007). Examining sense of belonging among first-year undergraduates from different racial/ethnic groups. Journal of College Student Development, 48(5), 525-542. https://doi.org/10.1353/csd.2007.0054

46. Jones, R. C. (2009). Sense of belonging and its relationship with quality of life and symptoms distress among undergraduate college students. PhD Dissertation, Faculty of the Graduate College, Oklahoma State University.

47. Kia-Keating, M. \& Ellis, B. H. (2007). Belonging and connection to school in resettlement: Young refugees, school belonging, and psychosocial adjustment. Clinical Child Psychology and Psychiatry. 12(1), 29-43. 
48. Koenraad, A. L. M. (2006). LanguageQuest design and telecollaboration. Teaching English with Technology, 6(3).

49. Koenraad, A. L.M. (2002). TalenQuest: WebQuests for modern languages. J. Colpaert, W. Decoo, M. Simons and S. Bueren, eds. CALL Professionals and the Future of CALL Research. Proceedings CALL 2002. Antwerp: University of Antwerp. 159-168.

50. Kroll T., Morris, J. (2009). Challenges and opportunities in using mixed method designs in rehabilitation research. Arch Phys Med Rehabil., 90(11,Suppl), 11-6. Doi: 10.1016/j.apmr.2009.04.023.

51. Levett-Jones, T., Lathlean, J., Maguire,J., \& McMillan, M. (2007). Belongingness: A critique of the concept and implications for nursing education. Nurse Education Today. 27, 210-218

52. Lovitts, B. E. (2001). Leaving the ivory tower: The causes and consequences of departure from doctoral study. Lanham, MD: Rowman \& Littlefield.

53. Lowenthal, P. R. (2009). Social presence. In P. Rogers, G. Berg, J. Boettcher, C. Howard, L. Justice, \& K. Schenk (Eds.), Encyclopedia of distance and online learning (2nd ed.). Information Science Reference.

54. Luzón, M. J. (2002). Internet content-based activities for ESP. English Teaching Forum, 40(3): 20-25.

55. Luzón, M. J. (2007) Enhancing Webquest for Effective ESP Learning. CORELL: Computer Resources for Language Learning, 1, 1-13.

56. Martin J. R., Swartz-Kulstad, J. L., \& Madson, M. (1999). Psychosocial Factors that Predict the College Adjustment of First-Year Undergraduate Students: Implications for College Counselors. Journal of College Counseling. 2(2).

57. Marzano, R. J. (1992). A different kind of classroom: Teaching with dimensions of learning. Alexandria, VA: Association for Supervision and Curriculum Development.

58. Marzano, R. J., \& Kendall, J. S. (2007). The new taxonomy of educational objectives. Thousand Oaks, CA: Corwin.

59. Maslow, A. H. (1954). Motivation and personality. New York, NY: Harper. 
60. Menzies, D. \& Davidson, B. (2002). Authenticity and Belonging: The Experience of Being Known in the Group. Group Analysis. 35(1), 4355.

61. Moore, M. G. (2007). Theory of transactional distance. In M. G. Moore (Ed.), Handbook of distance education (pp. 89-101). Mahwah, NJ: Lawrence Erlbaum.

62. MST, E. A. (2014). Effects of WebQuest on Content Knowledge Acquision and motivation of basic physics students. International Journal of Education and Research, 2(12):181-192.

63. Ngoyi, L. and Sandy Malapile L. J. (2018). Social Presence and Student Engagement in Online Learning, In: D. B. A., Mehdi Khosrow-Pour, (Eds.). Student Engagement and Participation: Concepts, Methodologies, Tools, and Applications (pp. 1228-1237). US: IGI Global. DOI: 10.4018/978-1-5225-2584-4.ch061

64. O'Meara, K., Griffin, K. A., Kuvaeva, A., Nyunt, G., \& Robinson, T. (2017). Sense of belonging and its contributing factors in graduate education. International Journal of Doctoral Studies, 12, 12, 251-279. https://doi.org/10.28945/3903

65. O'Reilly, T. (2005). What Is Web 2.0: Design Patterns and Business Models for the Next Generation of Software? http://www.oreillynet.com/pub/a/oreilly/tim/news/2005/09/30/wh at-is-web-20.html, Zugriff am 10.06.2007

66. O'Reilly, T. (2005). Web 2.0: Compact definition? Retrieved from http://radar.oreilly.com/archives/2005/10/web 20 compact d efinition.html

67. Oliver, D. (2010). The effect and value of a WebQuest activity on weather in a 5th grade classroom, Ph.D. thesis, Idaho State University, Pocatello, Idaho.

68. Orozco, M. G. and Martin, M. X. (2011). Exploring the impact of the implementation of a WebQuest for Learning English in a 5th Grade classroom of public classroom in Pereira Risaralda. Masters Dissertation, Universidad Technologica De Pereira.

69. Ostrove, J. M., Stewart, A. J., \& Curtin, N. L. (2011). Social class and belonging: Implications for graduate students' career aspirations. The Journal of Higher Education, 82(6), 748-774. 
70. Ottenbreit-Leftwich, A. T., Glazewski, K. D., Newby, T. J., \& Ertmer, P. A. (2010). Teacher value beliefs associated with using technology: Addressing professional and student needs. Computers \& Education, 55(3), 1321-1335. DOI: 10.1016/i.compedu.2010.06.002.

71. Picciano, A. (2002). Beyond student perceptions: issues of interaction, presence, and performance in an online course. Journal of Asynchronous Learning Networks, 6(1), 21- 40.

72. Pressman, S. D., Cohen, S., Miller, G. E., Barkin, A., Rabin, B.S., \& Treanor, J. J. (2005). Loneliness, Social Network Size, and Immune Response to Influenza Vaccination in College Freshmen. Health Psychology. 24(3), 297-306.

73. Puthikanon, N. (2009). Examining critical thinking and language use through the use of Webquests in an EFL reading class, Ph.D. Thesis, Indiana University, US.

74. Rettie, R. (2003). Connectedness, awareness, and social presence. Paper presented at the 6th International Presence Workshop, Aalborg, Denmark.

75. Riazi, A. M., \& Candlin, C. N. (2014). Mixed-methods research in language teaching and learning: opportunities, issues and challenges. Language Teaching, 47(2), 135-173.

76. Richards, C. (2005). The design of effective ICT-supported learning activities: Exemplary models, changing requirements, and new possibilities. Language Learning \& Technology, 9(1): 60-79.

77. Ridgeway, V.G., Peters, C.L., \& Tracy, T.S. (2002). Out of this world: Cyberspace, literacy, and learning. In C. C. Block, L. B. Gambrell, \& M. Pressley (Eds.), Improving comprehension instruction: Rethinking research, theory, and classroom practice (pp. 290-307). San Francisco: Jossey-Bass.

78. Rourke, L., Anderson, T., Garrison, D. R., \& Archer, W. (2001). Assessing social presence in asynchronous, text-based computer conferencing. Journal of Distance Education, 14(3) 51-70.

79. Rovai, A. P. (2002). Building sense of community at a distance. International Review of Research in open and distance Learning, 3(1). Available online, http://www.irrodl.org/content/v3.1/rovai.html. 
80. Rovai, A. P. (2003). In search of higher persistence rates in distance education online programs. The Internet and Higher Education, 6(1):1-16.

81. Salem, A. A. M. (2008). The Effectiveness of a Proposed Program Based on Using Workshops in Developing the Functional Writing Skills of Primary Stage Prospective Teachers of English. MA Thesis, Institute of Educational Studies, Cairo University.

82. Salem, A. A. M. (2013a). The Effect of Writer's Workshop Approach to Develop Functional Writing Skills of Primary Stage Pre-Service English Language Teachers in Egypt. International Journal of Applied Linguistics \& English Literature, 2(5), 70-80. Doi:10.7575/aiac.ijalel.v.2n.5p.70.

83. Salem, A. A. M. (2013b). The Effect of Using Writer's Workshop Approach on Developing Basic Writing Skills (Mechanics of Writing) of Prospective Teachers of English in Egypt. English Language Teaching, 6(7). Doi:10.5539/elt.v6n7p33 URL: http://dx.doi.org/10.5539/elt.v6n7p33.

84. Shafiee, S., Koosha, M., \& Afghari, A. (2013). The effect of conventional, web-based, and hybrid teaching of pre-writing strategies on Iranian EFL learners' writing performance. International Research Journal of Applied and Basic Sciences, 4(2): 393-401.

85. Short, J., Williams, E. \& Christie, B. (1976). The social psychology of telecommunications. London: John Wiley \& Sons.

86. Simina, V. \& Hamel, M. J. (2005). CASLA through a social constructivist perspective: WebQuest in project-driven language learning. ReCALL, 17 (2): 217-228.

87. Spiro, R. J., Coulson, R. L., Feltovich, P. J., \& Anderson, D. K. (1994). Cognitive flexibility theory: Advanced knowledge acquisition in illstructured domains. In R. B. Ruddell, M. R. Ruddell \& H. Singer (Eds.), Theoretical models and processes of reading (4th ed., pp. 602-615). Newark, DE: International Reading Association.

88. Stahl, G., Law, N., \& Hesse, F. (2013). Collaborative learning at CSCL 2013. International Journal of Computer-Supported Collaborative Learning, 8(3), 267-269. Doi: 10.1007/s11412-013-9179-y. 
89. Stebleton, M. J., Huesman, R. L., Jr. \& Kuzhabekova, A. (2010). Do I belong here? Exploring immigrant college student responses on the SERU survey sense of belonging/satisfaction factor. Research and Occasional Papers Series. Berkeley, CA: Center for Studies in Higher Education - University of California, Berkeley. Retrieved from https://escholarship.org/uc/item/6j6621ph\#page-8

90. Strayhorn, T. L. (2012). College students' sense of belonging: A key to educational success for all students. New York, NY: Routledge.

91. Swan, K. (2003b). Learning effectiveness online: What the research tells us. In J. Bourne \& J. C. Moore (Eds.), Elements of quality online education, practice and direction (pp. 13-45). Needham, MA: Sloan Center for Online Education.

92. Swan, K., \& Shea, P. (2005). The development of virtual learning communities. In S. R. Hiltz \& R. Goldman (Eds.), Asynchronous learning networks (pp. 239-260). New York: Hampton Press.

93. Tashakkori, A., \& Teddlie, C. (2003). Handbook of mixed methods in social \& behavioral research. Thousand Oaks: Sage.

94. Tu, C. (2002). The measurement of social presence in an online learning environment. International Journal on E-Learning, 1(2), 3445.

95. Tu, C.-H. (2000). On-line learning migration: From social learning theory to social presence theory in a CMC environment. Journal of Network and Computer Applications, 2, 27-37.

96. Tu, Ch. \& Marina Mclsaac, M. (2010). The Relationship of Social Presence and Interaction in Online Classes. American Journal of Distance Education, 16(3), 131-150. https://doi.org/10.1207/S15389286AJDE1603 2

97. Tuan, L. T. (2011). Teaching reading through WebQuest. Journal of Language Teaching and Research, 2(3): 664-673. Doi: 10.4304/jltr.2.3. 664-673

98. Walther, J. B. (1996). Computer-mediated communication: Impersonal, interpersonal, and hyperpersonal interaction. Communication Research, 23(1), 3-43. 
99. Walton, G.M., \& Cohen, G.L., (2007). A Question of Belonging: Race, Social Fit, and Achievement. Journal of Personality and Social Psychology. 92(1), 82-96.

100. Yalom, I. (2005). The Theory and Practice of Group Psychotherapy, Fifth Edition. New York: Basic Books.

101. Young, A. F., Russell, A., \& Powers, J. R. (2004). The sense of belonging to a neighborhood: Can it be measured and is it related to health and wellbeing in older women? Social Science \& Medicine, 59(12), 2627-2637. https://doi.org/10.1016/j.socscimed.2004.05.001 